\title{
Objective Structured Knowledge Exchange: A Novel Instructional Approach in Travel Medicine Education
}

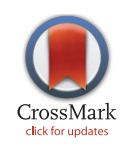

\author{
Gerard Thomas Flaherty ${ }^{1,2^{*}}$, Conor Maguire ${ }^{3}$, Simon Collins ${ }^{4}$ \\ ${ }^{1}$ School of Medicine, National University of Ireland Galway, Ireland \\ ${ }^{2}$ School of Medicine, International Medical University, Kuala Lumpur, Malaysia \\ ${ }^{3}$ Glencairn Medical Centre, Dublin, Ireland \\ ${ }^{4}$ Travel Health Clinic, Dublin, Ireland
}

Corresponding Author: Gerard Thomas Flaherty, MD, Professor, School of Medicine, National University of Ireland Galway, Ireland. Tel: +353-91495469, Fax: +353-91494540, Email: gerard.flaherty@nuigalway.ie

Received January 29, 2019; Accepted March 19, 2019; Online Published April 14, 2019

Citation: Flaherty GT, Maguire C, Collins S. Objective structured knowledge exchange: a novel instructional approach in travel medicine education Int J Travel Med Glob Health. 2019;7(2):69-70. doi:10.15171/ijtmgh.2019.15.

\section{Dear Editor,}

Travel medicine education should meet the learning needs of its target audience of travel medicine clinicians in practice and healthcare students. ${ }^{1}$ We are current or past presidents of the Travel Medicine Society of Ireland (TMSI). The TMSI was established in 1995, making it one of the longest standing national travel medicine professional societies. As one of 12 partner associations which collaborate in organizing the biennial Northern European Conference on Travel Medicine (NECTM), TMSI is actively involved in the provision of continuing professional development opportunities to practicing travel medicine physicians, nurses, and pharmacists.

Within the Republic of Ireland, the TMSI plays a leading role in raising the standards of travel medicine practice among its approximately 350 members (mostly general practitioners, but also practice nurses, pharmacists, and medical students) through its quarterly regional educational seminars, regular electronic newsletters, and annual masterclass. Invited external speakers supplement instruction from members of the executive committee, all of whom are expected to design and deliver relevant teaching to the society's members.

In advance of hosting the $4^{\text {th }}$ NECTM conference in 2012, we conceived and developed a novel educational approach to promoting greater interaction between instructors and learners attending our educational sessions. Thus, the Objective Structured Knowledge Exchange (OSKE) was created. A variation on the acronym of the well-established assessment method, the OSCE (Objective Structured Clinical Examination), the OSKE was piloted at TMSI seminars before being accepted as the preferred workshop format for the 2012
NECTM conference in Ireland. Our society has since adopted the OSKE for use at all of its educational events.

A typical half-day educational seminar features two cycles of OSKEs, each of 90 minutes duration. Each OSKE is facilitated by a member of the executive committee with a higher qualification in travel medicine or a related discipline. OSKE topics reflect the broad scope of travel medicine practice, including travel-related trauma and personal safety, ${ }^{2,3}$ and are accepted by the executive committee. Accreditation is obtained for each seminar from the Irish College of General Practitioners. The committee endeavors to include topics which relate to communicable and non-communicable travel health risks. There is also coverage of destination travel health risks according to geographic region. Topics of current importance, especially where a recent outbreak has occurred, are given priority. Members are encouraged to suggest topics to the executive committee based on their learning needs.

Participants rotate in small groups (10-15 individuals per group) between the three OSKE stations, with each 30-minute teaching session announced by a whistle blow. OSKE facilitators typically use teaching aids such as slides, handouts, or flipcharts, and there is a productive exchange of ideas between learners and instructors. OSKE facilitators prepare a short summary of their topic for submission to the subsequent issue of the society's newsletter. The OSKE format has also been very effectively deployed with larger group sizes at successive NECTM conferences in Dublin (2012), Bergen (2014), and London (2016).

Table 1 provides a content analysis of OSKEs delivered at TMSI educational events since 2012. Nearly half (47\%, $\mathrm{n}=37$ ) of the OSKEs are related to non-communicable disease

Copyright $\odot 2019$ The Author(s). This is an open-access article distributed under the terms of the Creative Commons Attribution License (http:// creativecommons.org/licenses/by/4.0), which permits unrestricted use, distribution, and reproduction in any medium, provided the original work is properly cited. 
Table 1. Coverage of OSKE Subjects in TMSI Educational Seminars, 2012-2018

\begin{tabular}{|c|c|c|c|}
\hline Communicable Disease Risks & OSKEs (n) & Non-communicable Disease Risks & OSKEs (n) \\
\hline Personal safety and security & 5 & Yellow fever vaccination & 5 \\
\hline Pregnant travelers & 4 & Vaccine administration & 4 \\
\hline Running a travel health clinic & 2 & Travelers' diarrhea & 3 \\
\hline Trekking Kilimanjaro & 2 & Malaria chemoprophylaxis & 3 \\
\hline Last minute travelers & 2 & Immunocompromised travelers & 2 \\
\hline Travel to altitude with pre-existing conditions & 1 & Viral haemorrhagic fevers, including Ebola & 2 \\
\hline Preparing a medical kit for travel & 1 & Schistosomiasis & 2 \\
\hline In-flight medical emergencies & 1 & Pediatric travelers & 2 \\
\hline Diabetic travelers & 1 & Pertussis & 1 \\
\hline Cruise ship travelers & 1 & Leishmaniasis & 1 \\
\hline Social media in travel medicine & 1 & Measles in travelers & 1 \\
\hline Hajj pilgrim risks & 1 & Persistent diarrhea in returning travelers & 1 \\
\hline Travel insurance & 1 & Cholera & 1 \\
\hline Medical tourism & 1 & Meningococcal vaccination & 1 \\
\hline Travel risk assessment & 1 & Respiratory infections during travel & 1 \\
\hline Preparing school volunteer groups & 1 & Non-falciparum malaria & 1 \\
\hline Traveling with epilepsy & 1 & Medicolegal risks of travel vaccination & 1 \\
\hline Sexual health in travel & 1 & Fever in returned travelers & \\
\hline Stem cell tourism & 1 & Travel vaccination dilemmas & 1 \\
\hline Reception of refugees & 1 & Chikungunya & 1 \\
\hline Controversies in travel medicine & 1 & Middle East Respiratory Syndrome-Coronavirus & 1 \\
\hline Volunteering tourism & 1 & West Nile infection & 1 \\
\hline Communicating risk to travelers & 1 & Zika virus infection & 1 \\
\hline Female travelers & 1 & Influenza & 1 \\
\hline Mature travelers & 1 & Standby treatment of malaria & 1 \\
\hline Diseases of the ear, nose and throat and travel & 1 & Melioidosis & 1 \\
\hline Sports tourism & 1 & & 1 \\
\hline Student travelers & 1 & & \\
\hline Venous thrombosis & 1 & & \\
\hline Cold extremes & 1 & & \\
\hline Repatriation of deceased travelers & 1 & & \\
\hline Water purification & 1 & & \\
\hline
\end{tabular}

travel health risks, with the remainder being devoted to communicable disease risks $(40 \%, \mathrm{n}=31)$ and destinationlevel topics $(13 \%, \mathrm{n}=10)$. The most frequently delivered OSKE topics include personal safety and security, pregnant travelers, vaccine administration, and yellow fever vaccine. The OSKE teaching format is consistent with pedagogical best practice in medical education. ${ }^{4}$ It has facilitated the greater engagement of delegates at our regional educational seminars. We recommend that it be adapted by other travel medicine professional societies in order to better address their members' learning needs.

\section{Authors' Contributions}

GTF led the conception of the manuscript and preparation of the first draft. CM and SC edited the first draft. All authors read and approved the final version.

\section{Conflict of Interest Disclosures}

None.

\section{Ethical Approval}

Not applicable.

\section{Funding/Support}

None.

\section{Acknowledgments}

The authors express their appreciation to Ms. Anne Redmond, Honorary Secretary of the Travel Medicine Society of Ireland (TMSI), for her assistance in collating educational programs from TMSI seminars and masterclasses, 2012-2018.

\section{References}

1. Thong Zi Yi C, Browne R, Flaherty G. The missing link: introducing travel medicine into the undergraduate medical curriculum. J Travel Med. 2016;23(5). doi:10.1093/jtm/taw038.

2. Flaherty GT, Lim Yap K. Bibliometric analysis and curriculum mapping of travel medicine research. J Travel Med. 2017;24(5):tax024. doi:10.1093/jtm/tax024.

3. Long IJ, Flaherty GT. Traumatic travels-a review of accidental death and injury in international travellers. Int J Travel Med Glob Health. 2018;6(2):48-53. doi:10.15171/ijtmgh.2018.10.

4. Ramani S. Twelve tips to promote excellence in medical teaching. MedTeach. 2006;28(1):19-23. doi:10.1080/01421590500441786. 